\title{
Superinfecting microorganisms in patients under treatment with cyclosporin-A and its correlation to gingival overgrowth
}

\section{Microrganismos superinfectantes em pacientes submetidos a terapia com ciclosporina-A e sua correlação com crescimento gengival}

\author{
Giuseppe Alexandre Romito* \\ Roberto Fraga Moreira Lotufo* \\ Luciana Saraiva** \\ Alessandro Nautili Pustiglioni*** \\ Francisco Emílio Pustiglioni ${ }^{* * * *}$ \\ Noedir Antônio Groppo Stolf*****
}

\begin{abstract}
The aim of this study was to identify the presence of superinfecting microorganisms (Gram-negative enteric rods and Candida $s p$.) in heart transplant patients and correlate this with gingival overgrowth. Thirty patients (10 females, 20 males - mean age 45 years) were examined. All were under cyclosporin-A (CsA) therapy. Patients who had taken any antibiotics 3 months prior the study or had been submitted to periodontal therapy were not enrolled. Patients were required to have at least 6 teeth. The plaque index (PI), gingival index (GI), pocket depth (PD) and clinical attachment level (CAL) were recorded. Microbiological samples were taken from sulcus/pocket (s/p) and from stimulated saliva (ss) and submitted to analysis. Patients were divided into two groups: the ones with gingival overgrowth (GO) and those without gingival overgrowth (WGO). After statistical analysis (chi-square test, Student's $t$-test, Fisher test, $\mathrm{p} \leq 0.05$ ), we concluded that there was no statistical difference between groups in the parameters of gender, CsA dosage, time since transplantation, PI, GI, PD and CAL. Gram-negative rods from either the sulcus/pocket or saliva samples were not found. Candida sp. was detected (s/p-30\% and ss $-30 \%)$. Stimulated saliva samples analysis determined that the presence of Candida $s p$. was associated with patients without gingival overgrowth.
\end{abstract}

DESCRIPTORS: Cyclosporine-A; Periodontics; Superinfection; Gingival hyperplasia.

\begin{abstract}
RESUMO: A proposta deste trabalho foi identificar a presença de microrganismos superinfectantes (bastonetes entéricos Gram-negativos e Candida $s p$.) em pacientes transplantados cardiacos e correlacioná-la com a presença de crescimento gengival. Foram examinados 30 pacientes (10 mulheres e 20 homens - média de idade: 45 anos). Todos os pacientes estavam sob terapia com ciclosporina-A (CsA) sem terem sido submetidos a antibioticoterapia e nem a tratamento periodontal prévio, por pelo menos três meses antes do início do estudo. O paciente deveria ter, no mínimo, seis dentes. Foram registrados os indices de placa bacteriana (IP), indice gengival (IG), valores de profundidade clínica de sondagem (PCS) e nível clínico de inserção (NCI). Análise microbiológica foi realizada a partir de amostras coletadas de sul$\mathrm{co} /$ bolsa gengival ( $\mathrm{s} / \mathrm{b}$ ) e da saliva estimulada (se). Os pacientes foram divididos em dois grupos: com crescimento gengival (CCG) e sem crescimento gengival (SCG). Após análise estatística (teste do qui-quadrado; teste $t$ de Student; prova exata de Fisher; $p \leq 0,05$ ), concluiu-se que não houve diferença entre os dois grupos de pacientes com relação a sexo dos pacientes, dosagem de CsA, tempo decorrido após o transplante, IP, IG, PCS e NCI. O exame microbiológico das amostras coletadas mostrou a ausência de bastonetes entéricos Gram-negativos. Foi possivel a detecção de Candida sp. (s/b-30\% e se-30\%). Na amostra de saliva estimulada a presença desse microrganismo estava associada aos pacientes SCG.
\end{abstract}

DESCRITORES: Ciclosporina-A; Periodontia; Super-infecção; Hiperplasia gengival.

\section{INTRODUCTION}

The first cases of gingival overgrowth (GO) associated with the use of cyclosporin-A (CsA) were reported by Rateitschak-Plüss et al. ${ }^{18}$ (1983). Since then, various studies have been undertaken to try and elucidate the pathogenesis of this conditi on ${ }^{4,13,19,20,25}$. Among patients that take CsA, only $50 \%$ suffer some kind of GO. This difference in adverse response found within a given population can be due to genetic predisposition or local conditions $^{8}$.

\footnotetext{
*Assistant Professor; **PhD; ***MSc; ****Associate Professor, Discipline of Periodontics, Department of Stomatology, School of Dentistry; ${ }^{* * * * A s s o c i a t e ~ P r o f e s s o r, ~ H e a r t ~ I n s t i t u t e, ~ S c h o o l ~ o f ~ M e d i c i n e ~-~ U n i v e r s i t y ~ o f ~ S a ̃ o ~ P a u l o . ~}$
} 
Romito GA, Lotufo RFM, Saraiva L, Pustiglioni AN, Pustiglioni FE, Stolf NAG. Superinfecting microorganisms in patients under treatment with cyclosporin-A and its correlation to gingival overgrowth. Pesqui Odontol Bras 2003;17(1):35-40.

There are differences in gingival response to the use of this drug due to the large number of interand intrapatient variables, such as age, dosage, length of treatment, concomitant use of other drugs, systemic conditions, the patient's ability to adequately control plaque and the presence of local predisposing factors ${ }^{20}$.

There is, hence, the need for greater understanding of the etiology and pathogenesis of GO. Some aspects still need to be elucidated as to the degree of GO and the complexity of the local factors involved, including local microbial flora, especially superinfecting microorganisms acting on immunosupressed patients. Seymour, Smith ${ }^{20}$ (1991) evaluated the efficiency of plaque control in 27 renal transplant patients. The patients were divided into two groups: 1) without professional plaque control and 2) with professional plaque control. After six months, the authors concluded that plaque control does not determine the presence or absence of GO.

Montebugnoli et al. ${ }^{16}$ (1996) examined 39 heart transplant patients. The results showed no correlation between the analysed variables (age, sex, plaque index, gingival index, CsA dose, serum concentration of CsA) and GO. A positive correlation was found between therapy with CsA and the duration of treatment with the drug, suggesting that the relationship between treatment with $\mathrm{CsA}$ and GO could be time-dependant and that the influence of CsA on periodontal condition could spontaneously diminish with time.

In disagreeing with the aforementioned studies, Somacarrera et al. ${ }^{23}(1994)$ reported that there is a strong correlation between the location of GO and the presence of plaque. Thus, the elimination of plaque would be an efficient measure for preventing that alteration of gingival tissue. In a subsequent study, in which 100 (heart, kidney or liver) transplant patients were followed for six months, Somacarrera et al. ${ }^{24}$ (1994) concluded that an oral hygiene programme preceding transplant surgery is recommendable.

It can be said that there is no consensus by those different authors. Perhaps this is a result of the fact that different techniques of analysis were employed to evaluate the association of the use of CsA with the occurrence and extension of GO. Thus, several aspects related to dosage, length of treatment, presence of local etiologic factors and modifying factors still need to be analysed in these patients. Up to this moment, no study has gone to the trouble of analysing the oral microbial flora harbored by these patients. The aim of this study was to determine the presence of superinfecting microorganisms and correlate this condition with the presence or absence of gingival overgrowth in heart transplant patients.

\section{MATERIALS AND METHODS}

Thirty heart transplant patients (10 female, 20 male) from the Heart Institute (INCOR), School of Medicine, University of São Paulo, participated in this study, which was submitted to and authorised by the Ethics Committee of the aforementioned School. Patients who had not been submitted to antimicrobial therapy or periodontal treatment three months prior to the commencement of the study were enrolled. Patients participating were required to have at least six erupted teeth.

\section{Clinical examination}

A clinical periodontal examination was carried out by a single trained examiner. With the aid of a periodontal probe, pouches were examined and the largest probing values obtained for each of the following regions were taken down: distobuccal, centrobuccal, mesiobuccal, distolingual, centrolingual and mesiolingual. The following clinical parameters were annotated: 1) Clinical probing depth (PD); 2) Clinical attachment level (CAL); 3) Gingival index (GI)*; 4) Plaque index (PI)**. During clinical examination, the characterization of GO was carried out in a dicotomic manner: either presence or absence.

\section{Microbiological examination \\ Subgingival collection}

Four collection sites were chosen for microbiological examination, the ones that presented the largest PD in each quadrant. When this condition could not be fulfilled, samples were collected respecting the best distribution among the teeth present in each quadrant. For the microbiological collection, teeth were previously isolated with cotton rolls and supragingival plaque was removed with the help of periodontal curettes***. Subgingival samples were obtained by introducing tips of

\footnotetext{
*Löe \& Silness.
}

**Silness \& Löe. 
Romito GA, Lotufo RFM, Saraiva L, Pustiglioni AN, Pustiglioni FE, Stolf NAG. Superinfecting microorganisms in patients under treatment with cyclosporin-A and its correlation to gingival overgrowth. Pesqui Odontol Bras 2003;17(1):35-40.

sterile blotting paper within the gingival pocket. The paper tips were maintained in locu for approximately 20 seconds $^{9}$. After their removal, they were placed in vials containing glass beads and $2 \mathrm{ml}$ of VMGA III transport medium.

\section{Collection of saliva}

For the collection of saliva, the patients were asked to chew paraffin ${ }^{* * * *}$ with the intent of stimulating the production of saliva. The initial accumulation of saliva was discarded. Subsequent accumulations were collected into sterile tubes ${ }^{* * * * *}$ until a volume of at least $10 \mathrm{ml}$ was reached.

\section{Processing of samples in the laboratory}

The vials were shipped to the lab up to 2 hours after sample collection. Samples in VMGA III were mechanically homogenized for 20 seconds in order to separate aggregated microbial clumps. Next, the samples were serially diluted in sterile $0.85 \%$ sodium chloride solution. With the aid of a sterile pipette, $100 \mu \mathrm{l}$ aliquots of $1: 10,1: 100$ and $1: 1.000$ dilutions were spread on petri dishes containing selective culture media ${ }^{30}$. The saliva samples were serially diluted up to 1:10.000. Identification of bacteria was carried out according to the techniques described by Slots ${ }^{21}$ in 1986. The studied microorganisms were: Gram-negative enteric rods and Candida $s p$.

\section{RESULTS}

The age of patients participating in the study varied from 13 to 67 years (with a mean of 45 years).

Table 1 displays the number of patients that presented GO. This table shows the distribution of GO among male and female patients. Independent of sex, the table shows that out of the 30 patients eval-

TABLE 1 - Distribution of patients according to gender and presence or absence of gingival overgrowth. Chi-square test.

\begin{tabular}{l|c|c|c}
\hline \hline \multicolumn{4}{c}{ Gingival overgrowth } \\
\hline \multicolumn{1}{c|}{ Sex } & Negative & \multicolumn{1}{c}{ Positive } & Total \\
\hline Female & $4(40 \%)$ & $6(60 \%)$ & $10(100 \%)$ \\
\hline Male & $6(30 \%)$ & $14(70 \%)$ & $20(100 \%)$ \\
\hline Total & $10(33 \%)$ & $20(67 \%)$ & $30(100 \%)$ \\
\hline \hline
\end{tabular}

Chi-square: 0.30; degrees of freedom: $1 ; \mathrm{p}=0.584$. uated, $20(67 \%)$ presented GO. To check if there was any statistically significant difference between both groups, the chi-square test was applied. This test showed no difference between male and female patients in relation to prevalence of GO.

The results were divided into those of patients who presented GO and those who did not present GO. Student's $t$-test was applied in order to verify if there was association between the presence of GO and the periodontal clinical parameters analysed. This test showed that there was no statistically significant difference between the groups (Table 2).

Microbiological analysis did not detect the presence of Gram-negative rods in the samples collected from the grooves nor in saliva samples, thus, statistical analysis for this class of bacteria was not carried out. However, yeasts belonging to the Candida genus were isolated in both groups (Graph 1) and the association of their presence with that of GO was verified with the saliva samples.

In Graph 1, the number of patients and the percentage of which presented the presence of yeasts of the Candida genus in both groups are shown. The microorganism was not present in $81 \%$ of the patients who presented GO. In $67 \%$ of the patients that did not present GO, the microorganism was present.

TABLE 2 - Results of Student's $t$-test for comparison between WGO and GO areas and clinical parameters: time since transplantation (years), dosage (CsA mg/day), GI, PI, PD and CAL.

\begin{tabular}{|c|c|c|c|c|}
\hline $\begin{array}{c}\text { Compared } \\
\text { groups }\end{array}$ & Parameter & $t$ & $\begin{array}{l}\text { Degrees of } \\
\text { freedom }\end{array}$ & $\mathrm{p}$ \\
\hline \multirow{6}{*}{$\begin{array}{c}\text { WGO } \\
\text { and } \\
\text { GO }\end{array}$} & $\begin{array}{c}\text { Time since } \\
\text { transplantation }\end{array}$ & -1.6057 & 28 & $0.1196(\mathrm{~ns})$ \\
\hline & CsA & 0.3613 & 28 & $0.7206(\mathrm{~ns}$ \\
\hline & GI & 0.3397 & 28 & $0.5408(\mathrm{~ns}$ \\
\hline & PI & 0.0993 & 28 & $0.6614(\mathrm{~ns})$ \\
\hline & PD & -0.9718 & 28 & $0.3394(\mathrm{~ns})$ \\
\hline & CAL & -0.1595 & 28 & $0.8744(\mathrm{~ns})$ \\
\hline
\end{tabular}

ns: not significant. WGO: without gingival overgrowth; GO: with gingival overgrowth; CsA: cyclosporin-A; GI: gingival index; PI: plaque index; PD: pocket depth; CAL: clinical attachment level.

\footnotetext{
***Hu-Friedy - Gracey curettes nos. 5/6, 11/12 or 13/14.

****Parafilm "M" - Laboratory Film - American National Can - Chicago, IL. 60631.

$* * * * *$ Labcon, North America $-50 \mathrm{ml}$, centrifuge tubes with screw caps, disposable/graduated/conical/sterile.
} 
Romito GA, Lotufo RFM, Saraiva L, Pustiglioni AN, Pustiglioni FE, Stolf NAG. Superinfecting microorganisms in patients under treatment with cyclosporin-A and its correlation to gingival overgrowth. Pesqui Odontol Bras 2003;17(1):35-40.

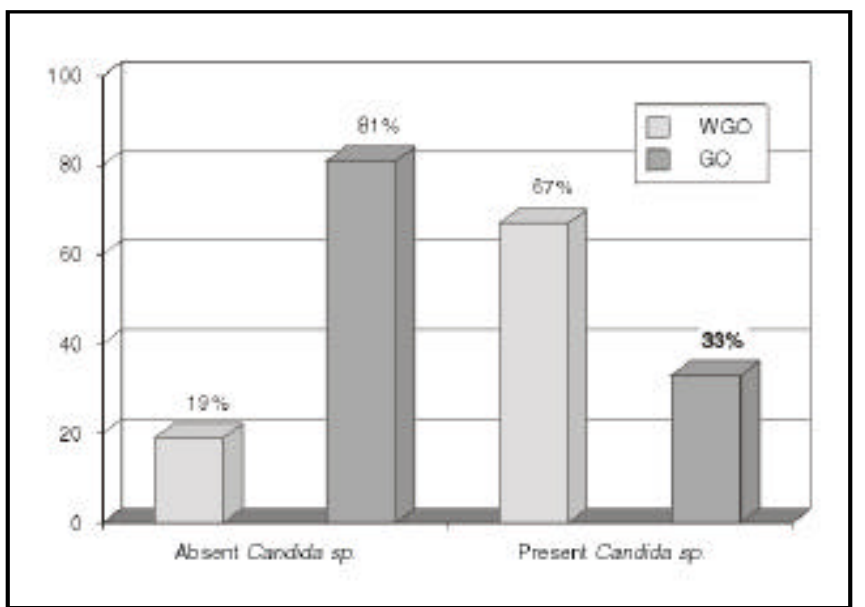

GRAPH 1 - Percentage of patients according to the presence or absence of Candida $s p$. in saliva. WGO: without gingival overgrowth; GO: with gingival overgrowth.

\section{DISCUSSION}

The fact that CsA induces GO is common knowledge to researchers. However, recent studies have concentrated efforts on the identification of possible risk factors that can predispose to the problem and present yet unresolved doubts ${ }^{15}$. In view of this, we attained to verify whether there is a relationship between the presence of a superinfecting oral flora and GO in patients that make use of CsA.

When we compare the clinical parameters evaluated (time since transplantation, dose of CsA taken, PI, GI, PD, and CAL) in both groups, we verify that there is no statistically significant difference between them. This result corroborates the study by Seymour, Smith ${ }^{20}$ (1991), who found that the initial periodontal condition is not a determining factor for GO. The occurrence of GO would be associated with the individual response of each patient.

Only Fischer, Klinge ${ }^{6}$ (1996) have gone to the trouble of experimentally analysing the possible correlation between microorganisms and GO. Our study has qualitatively evaluated the microbial flora of patients that make use of CsA.

Microbiological analysis results show the presence of Candida sp. in gingival pockets. It is known that these microorganisms can be associated with destructive periodontal illness ${ }^{7}$.

When the presence of Candida $s p$. was analysed among patients with and without GO, we verified that only the saliva sample presented a statistically significant difference and was strongly asso- ciated with patients without GO. This type of microorganism, when found in the periodontal pocket, is in small number and is considered as being part of a transient microbial flora. However, in immunosupressed individuals, yeasts can thrive in large numbers ${ }^{2}$. In $30 \%$ of our patients, this microorganism was detected in both groove and saliva samples. Available literature shows that the prevalence of Candida $s p$. is of approximately $10 \%^{2}$, and is not related to either sex or age of the patients ${ }^{22}$.

We were unable to find in literature any explanation for Candida sp. being more present in saliva samples of patients without GO. One would expect that, due to GO, a more propitious environment for harbouring this microorganisms would be generated. According to McGaw et al. ${ }^{13}$ (1987), plaque would serve as a reservoir of CsA, and in this way would be lowering the patient's resistance to infection by C. albicans ${ }^{29}$.

According to Little, Rhodus ${ }^{12}$ (1992), all heart transplant candidate patients should extract all teeth with advanced periodontal alterations. The same is valid for patients who for some reason are under untreatable periodontal condition. This scenario was not the case in our study. Several patients were suffering from periodontal illness with evident presence of small gingival abscesses in the most affected regions, having not been instructed as to proper periodontal care, according to themselves.

It is evident that, through the clinical and microbiological results achieved by this study, periodontal care was not taken, nor were patients submitted to adequate periodontal treatment or support treatment following surgery.

Based on these data, one can conclude that if periodontal condition were determinant for the success or failure of heart transplantation, post-operative mortality would be much greater. In a retrospective study by Meyer et al. ${ }^{15}$ (1999), involving 74 heart transplant patients, the effect of points of teeth infection on survival and rejection was evaluated. They concluded that patients who suffer from severe cardiac failure symptoms do not need to be submitted to rigorous dental treatment preceding transplant surgery.

Clinical and microbiological periodontal condition may not be directly associated with the success of heart transplantation; however, these patients may end up presenting cardiovascular disease in the future. Individuals with periodontal 
Romito GA, Lotufo RFM, Saraiva L, Pustiglioni AN, Pustiglioni FE, Stolf NAG. Superinfecting microorganisms in patients under treatment with cyclosporin-A and its correlation to gingival overgrowth. Pesqui Odontol Bras 2003;17(1):35-40.

disease may have a significant increase in risk of coronary disease and its related events ${ }^{1}$. Periodontopathogens may contribute to atherogenic changes and thromboembolic episodes in the coronary arteries ${ }^{10}$.

It is a misconception to think that the risk of bacteremia only exists in invasive procedures. According to Pallasch, Slots ${ }^{17}$ (1996), dentists are frequently accused of causing infectious endocarditis, cerebral abscesses and infection in orthopaedic prostheses, if these infections occur days or months following dental therapy. These infections can be easily avoided with the correct use of prophylaxis with antibiotics ${ }^{3}$. When the risk of bacteremia caused by routine procedures carried out by the patients (such as mechanical control of plaque and even mastication) was evaluated, the occurrence of transient bacteremia was verified. This represents a much greater cumulative risk than that posed by dental procedures ${ }^{5}$. The presence of bacteremia and endocarditis in heart transplant patients was one of the finds in the study by Uip et al. ${ }^{27}$ (1996). The risk of death by infectious endocarditis seems to be high following heart transplantation ${ }^{26}$. The presence of Candida

\section{REFERENCES}

1. American Academy of Periodontology. Parameter on periodontitis associated with systemic conditions. J Periodontol 2000;71:876-9.

2. Dahlén G, Wikström M. Occurrence of enteric rods, staphylococci and Candida in subgingival samples. Oral Microbiol Immunol 1995;10:42-6.

3. Dajani AS, Taubert KA, Wilson W, Bolger AF, Bayer A, Ferrieri $\mathrm{P}$ et al. Prevention of bacterial endocarditis. Recommendations by the American Heart Association. J Am Med Assoc 1997;277:1794-801.

4. Daley TD, Wysocki GP, Day C. Clinical and pharmacologic correlations in cyclosporine-induced gingival hyperplasia. Oral Surg Oral Med Oral Pathol 1986;62:417-21.

5. Durack DT. Prevention of infective endocarditis. N Engl J Med 1995;332:38-44.

6. Fischer RG, Klinge B. Clinical and histological evaluation of ligature-induced periodontal breakdown in domestic ferrets immunosupressed by Cyclosporin-A. J Clin Periodontol 1994;21:240-9.

7. Haffajee AD, Socransky, SS. Microbial etiological agents of destructive periodontal diseases. Periodontol 2000 1994;5:78-111.

8. Hallmon WW, Rossmann JA. The role of drugs in the pathogenesis of gingival overgrowth. Periodontol 2000 1999;21:176-96. $s p$. in these patients should be further investigated. This microorganism can multiply and compete with periodontal pathogens in deep pockets, causing a greater loss of insertion ${ }^{2}$. Moreover, the presence of fungal infections in 100 heart transplant patients showed that this type of infection was responsible for a rise in mortality ${ }^{28}$.

The mechanism that regulates the occurrence of GO in patients submitted to therapy with CsA is multifactorial and still needs to be elucidated ${ }^{8}$. The presence of GO in these patients is not only important, but the clinical periodontal condition must be thoroughly reevaluated, for it is, without any doubt, a risk factor for systemic problems.

\section{CONCLUSIONS}

Gram-negative enteric rods were not isolated from groove samples or saliva samples. Yeasts of the Candida genus were positively identified in $30 \%$ of the patients, in either groove or saliva samples. Its presence was associated with the absence of gingival overgrowth. The presence of Candida $s p$. in periodontal pockets and in the saliva of patients submitted to immunosuppressant therapy can be a risk factor for postoperative complications.

9. Hartroth B, Seyfahrt I, Conrads, G. Sampling of periodontal pathogens by paper points: evaluation of basic parameters. Oral Microbiol Immunol 1999;14:326-30.

10. Herzberg MC, Meyer MW. Effects of oral flora on platelets: possible consequences in cardiovascular disease. J Periodontol 1996;67:1138-42.

11. Kantarci A, Cebeci I, Tuncer O, Carin M, Firatli E. Clinical effects of periodontal therapy on the severity of cyclosporin A-induced gingival hyperplasia. J Periodontol 1999; 70:587-93.

12. Little JW, Rhodus NL. Dental management of heart transplant patient. Gen Dent 1992;40:126-31.

13. McGaw T, Lam S, Coates J. Cyclosporin-induced gingival overgrowth: correlation with dental plaque scores, gingivitis scores, and cyclosporin levels in serum and saliva. Oral Surg Oral Med Oral Pathol 1987;64:293-7.

14. Mealey BL. Periodontal implications: medically compromised patients. Ann Periodontol 1996;1:256-321.

15. Meyer U, Weingart D, Deng MC, Scheld HH, Joos U. Heart transplants - assessment of dental procedures. Clin Oral Investig 1999;99:79-83.

16. Montebugnoli L, Bernardi F, Magelli C. Cyclosporin-A-Induced gingival overgrowth in heart transplant patients. A cross-sectional study. J Clin Periodontol 1996;23:868-72.

17. Pallasch TJ, Slots J. Antibiotic prophylaxis and medically compromised patient. Periodontol 2000 1996;10:107-38. 
Romito GA, Lotufo RFM, Saraiva L, Pustiglioni AN, Pustiglioni FE, Stolf NAG. Superinfecting microorganisms in patients under treatment with cyclosporin-A and its correlation to gingival overgrowth. Pesqui Odontol Bras 2003;17(1):35-40.

18. Rateitschak-Plüss EM, Hefti A, Lortscher R, Thiel G. Initial observation that cyclosporin-A induces gingival enlargement in man. J Clin Periodontol 1983;10:237-46.

19. Schincaglia GP, Trombelli L, Zangari F, Scabbia A, Griselli A, Calura G. Aumento di volume gengivale nei pazienti in trattamento con cyclosporina-A. Minerva Stomatol 1994; 43:429-34.

20. Seymour RA, Smith DG. The effect of a plaque control programme on the incidence and severity of cyclosporin-induced gingival changes. J Clin Periodontol 1991;18:107-10.

21. Slots J. Rapid identification of important microorganisms by cultivation. Oral Microbiol Immunol 1986;1:49-55.

22. Slots J, Feik D, Rams TE. Age and sex relationships of superinfecting microorganisms in periodontitis patients. Oral Microbiol Immunol 1990;5:305-8.

23. Somacarrera ML, Hernandez G, Acero J, Moskow BS. Factors related to the incidence and severity of cyclosporin-induced gingival overgrowth in transplant patients. A longitudinal study. J Periodontol 1994;65:671-5.

24. Somacarrera ML, Hernandez G, Acero J, Moskow BS. Localization of gingival overgrowth in heart transplant pa- tients undergoing cyclosporine therapy. J Periodontol 1994;65:666-70.

25. Thomason JM, Seymour RA, Ellis JS, Kelly PJ, Parry G, Dark J, et al. Iatrogenic gingival overgrowth in cardiac transplantation. J Periodontol 1995;66(8):742-6.

26. Uip DE, Amato Neto V, Strabelli TM, Bocchi EA, Pileggi F, Jatene AD, et al. Endocardite infecciosa em 100 pacientes submetidos a transplante cardiaco. Arq Bras Cardiol 1996;66:1-3.

27. Uip DE, Amato Neto V, Strabelli TM, Bocchi EA, Pileggi F, Jatene $\mathrm{AD}$, et al. Infecções bacterianas em 100 pacientes submetidos a transplante cardiaco. Arq Bras Cardiol 1996;66:135-7.

28. Uip DE, Amato Neto V, Varejão Strabelli TM, Alcides Bocchi $\mathrm{E}$, Fiorelli A, Stolf N, et al. Infeções fúngicas em 100 pacientes submetidos a transplante cardiaco. Arq Bras Cardiol 1996;66:65-7.

29. Vecchiarelli A, Cenci E, Marconi P, Rossi R, Riccardi C, Bistoni F. Immunosuppressive effect of cyclosporin on resistance to systemic infection with Candida albicans. J Med Microbiol 1989;30:183-92.

30. Zambon JJ, Reynolds HS, Slots J. Black-pigmented Bacteroides $s p$. in the human oral cavity. Infect Immun 1981;32:198-203.

\section{Scientific Electronic Library Online

\author{
http://wowviv.scielo.br \\ Parceria: FAPESP/BIREME
}

SciELO - Scientific Electronic Library Online é uma coleção eletrônica de revistas científicas disponíveis na Internet. A coleção traz os textos completos de artigos científicos, bases de dados e relatórios de uso e de impacto da literatura científica publicada no site.

Em operação desde 1997, atualmente estão disponíveis 29 revistas brasileiras nas áreas de Ciências Biológicas e da Saúde, Ciências Sociais e Humanas, Ciências Agrárias, Física etc. Novas publicaçôes são incluídas regularmente em várias especialidades.

Entre as revistas de nossa coleção, está a Pesquisa Odontológica Brasileira.

Consulte a Pesquisa Odontológica Brasileira (Revista de Odontologia da USP) na SciELO - http://www.scielo.br/rousp 